\title{
NESTING BIOLOGY OF Trypoxylon (Trypargilum) lactitarse SAUSSURE (HYMENOPTERA, CRABRONIDAE) IN TRAP-NESTS IN SOUTHERN BRAZIL
}

\author{
BUSCHINI, M. L. T., NIESING, F. and WOLFF, L. L. \\ Depto de Biologia, UNICENTRO, Rua Presidente Zacarias, 875, CEP 85010-990, Guarapuava, PR, Brasil \\ Correspondence to: Maria Luisa Tunes Buschini, Depto de Biologia, UNICENTRO, Rua Presidente Zacarias, 875, \\ CEP 85010-990, Guarapuava, PR, Brasil, e-mail: isatunes@yahoo.com.br \\ Received September 27, 2004 - Accepted February 2, 2005 - Distributed August 31, 2006
}

(With 6 figures)

\begin{abstract}
This study was carried in the Parque Municipal das Araucárias in the municipality of Guarapuava, state of Paraná, Southern Brazil. Three hundred and sixty five nests of T. lactitarse were obtained using trapnests of $0.7,1.0$, and $1.3 \mathrm{~cm}$ in diameter. All of them had similar architecture, regardless of the diameter of the trap-nest. Completed nests consisted of a linear series of brood cells whose average number per nest was of 3.3, 4.0 and 3.6 for the nests with $0.7 \mathrm{~cm}, 1.0 \mathrm{~cm}$ and $1.3 \mathrm{~cm}$ in diameter, respectively. They were constructed more often during the summer. . lactitarse had two types of life cycles: direct development (without diapause), and delayed development (with diapause during winter). Natural enemies included Chrysididae, Sarcophagidae, Dolichopodidae and Ichneumonidae. Out of 1,353 identified spider prey, 1,313 belonged to the Araneidae family.
\end{abstract}

Keywords: Trypoxylon lactitarse, Crabronidae, nesting biology, trap-nest, Hymenoptera.

\section{RESUMO}

\section{Biologia de nidificação de Trypoxylon (Trypargilum) lactitarse saussure (Hymenoptera, Crabronidae) em ninhos armadilhas no sul do Brasil}

Esse estudo foi realizado no Parque Municipal das Araucárias, no Município de Guarapuava (PR), Sul do Brasil. Trezentos e sessenta e cinco ninhos de $T$. lactitarse foram obtidos utilizando-se ninhos armadilhas de 0,7,1,0 e 1,3 cm de diâmetro. Todos apresentaram arquitetura similar, independente de seus diâmetros, sendo formados por uma série linear de células, cujo número médio foi de 3,3, 4,0 e 3,6 para os ninhos com $0,7,1,0$ e 1,3 cm de diâmetro, respectivamente. Os ninhos ocorreram com maior frequência no verão. T. lactitarse teve dois tipos de ciclo: um direto sem diapausa, e outro mais longo com entrada em diapausa. Seus inimigos naturais foram: Chrysididae, Sarcophagidae, Dolichopodidae e Ichneumonidae. Das 1.353 aranhas identificadas, 1.313 foram da família Araneidae.

Palavras-chave: Trypoxylon lactitarse, Crabronidae, biologia de nidificação, ninho armadilha, Hymenoptera.

\section{INTRODUCTION}

Trypoxylon (Trypargilum) lactitarse has a very extensive geographical range, occurring from Southern Canada to Southern Argentina (Coville, 1981). Wasps of this species are solitary, building their nests in preexisting cavities. Several aspects of their biology can be readily studied because they can be attracted to wooden blocks with holes drilled in their ends, commonly known as "trapnests" (Beyer et al., 1987).

Several studies focused on the biology of species in the subgenus Trypargilum in Brazil (Camillo et al., 1993; Perez-Maluf, 1993; Camillo et al., 1994; Camillo et al., 1995; Assis \& Camillo, 1997; Morato \& Campos (2000); Camillo \& Brescovit, 1999ab; Aguiar, 2002; Peruquetti \& 
Del Lama, 2003). These studies indicated that nest architecture is conserved within this group: females start the construction of their nest with a layer of mud, followed by the formation of a linear series of 6-8 cells, with mud partitions between them. Cells are provisioned with paralyzed spiders. In this subgenus, a male usually guards the nest while it is being provisioned by the female, chasing away ants, parasitic flies and cuckoo wasps and defending it against conspecific males (Brockmann \& Grafen, 1989).

According to Brockmann \& Grafen (1989), the size and perhaps the fecundity and life-span of adult wasps depends on the amount of food they consumed as larvae, given that these animals eat little as adults. Camillo \& Brescovit (1999b) studied the prey species collected by $T$. lactitarse and by T. rogenhoferi Camillo \& Brescovit (2000) in Southeastern Brazil. Both wasps preyed on a large range of spider species (5 and 10 families, respectively) and araneid (orb-weaving) spiders were their most commonly used prey item.

Although several authors have investigated aspects of the distribution, life-history, prey, nesting habit and parasites of T. lactitarse in Brazil (PerezMaluf, 1993; Camillo et al., 1993; Camillo et al., 1994; Assis \& Camillo, 1997; Camillo \& Brescovit, 1999ab) and in Costa Rica (Coville, 1981), nothing is known about this species in Southern Brazil. In this paper we present information obtained from trap-nests concerning the nesting biology of $T$. lactitarse in three different habitats in the south of Brazil.

\section{MATERIALS AND METHODS}

\section{Study area}

This study was carried out in the Parque Municipal das Araucárias in the municipality of Guarapuava, state of Paraná, Southern Brazil $\left(25^{\circ} 23^{\prime} 36^{\prime \prime} \mathrm{S}-51^{\circ} 27^{\prime} 19^{\prime \prime} \mathrm{W}, 1,120 \mathrm{~m}\right.$ above sea level). According to Koeppen's climatic classification, the region of Guarapuava is characterized by a humid and superhumid mesothermic climate without a dry season. Summers are mild, with an average temperature of $22{ }^{\circ} \mathrm{C}$ during the warmest months. Frosts are common and often severe during the winter, having an average temperature in the coldest month around $12.0^{\circ} \mathrm{C}$.

\section{Sampling program}

Nests of T. lactitarse were obtained using trapnests of $0.7,1.0$, and $1.3 \mathrm{~cm}$ in diameter and 8.0 $\mathrm{cm}$ in length. Each nest was placed $1.5 \mathrm{~m}$ above the ground and was inspected every two weeks. In each inspection, all occupied nests were immediately replaced with empty traps of the same diameter and then brought to the laboratory to investigate their contents. If eggs and/or larvae were present, the nest was closed back to allow the completion of the life-cycle and the emergence of the adults. Spiders containing wasp eggs or recently hatched larvae were removed, weighed and placed back inside their cells of origin. Recently emerged adults were carefully removed and weighed. The volume of the cells was estimated using a cylinder formula.

Collections were carried out over 3 years, which were divided into two periods, from April, 2000 to April, 2002 and from December, 2001 to December, 2003. In the first period collections were concentrated in a very heterogeneous site which included Araucaria forests, swamps and grasslands. In each habitat, 24 points were marked $2.5 \mathrm{~m}$ apart from one another along two perpendicular transects. Two of these points were randomly chosen in each transect to harbor three $1 \mathrm{~cm}$ trapnests. In the second period, 2 areas were studied in the Araucaria forest, Swamps and Grasslans, with 2 transects per area and 4 sampling stations per transect. One of these points was randomly chosen and the other 3 points were marked $15 \mathrm{~m}$ apart from one to another by systematic sampling. Each sampling station had 12 trap nests, four of which had an opening diameter $(0.7,1.0$ and $1.3 \mathrm{~cm}$, respectively), for an overall total of 576 traps. The humidity and temperature of each habitat were measured with a digital thermohygrometer throughout both sampling periods.

\section{Data analysis}

Mann-Whitney and Kruskal-Wallis nonparametric tests were used to test the null hypothesis relating nest architecture, cocoon morphology and premature development time. Variation in adult body mass was analyzed using an analysis of variance (ANOVA), followed by a posteriori comparisons using the Tukey test whenever appropriate.

The sex ratio was calculated by the ratio between the number of females and number of males, and the chi-square test was used to check 
the extent by which the observed sex ratio deviated from the expected frequency ( 1 female: 1 male).

\section{RESULTS}

\section{Seasonality and nesting activity in different habitats}

A total of 365 nests of $T$. lactitarse were collected in our study, 26 during the first and 339 during the second sampling period, respectively. Nests were more frequently found in the Araucaria forest than in the grassland and swamp areas (Fig. 1), the coolest and most humid habitat in the study site (Figs. 2 and 3).

Nests were constructed more often during the summer (between December and March) in both sampling periods (Figs. 4 and 5), following periods of high temperature (Fig. 2).

\section{Nest architecture}

T. lactitarse nested in all three types of trapnests and were most frequent in trap-nests with $1.0 \mathrm{~cm}$ in opening diameter (henceforth $1.0 \mathrm{~cm}$ trap-nest, $\mathrm{n}=167$ ), followed by $0.7 \mathrm{~cm}$ trap-nests $(\mathrm{n}=116)$ and were least frequent in $1.3 \mathrm{~cm}$ - trapnests $(n=56)$. All nests had similar architecture, regardless of the diameter of the trap-nest (Fig. 6).

The average nest length was $7.41 \mathrm{~cm}$ in the trap-nests with $0.7 \mathrm{~cm}$ in diameter, $7.33 \mathrm{~cm}$ in those with $1.0 \mathrm{~cm}$ and $6.81 \mathrm{~cm}$ in the trap-nests with $1.3 \mathrm{~cm}$ in diameter (Table 1). Their medians were not significantly different (Kruskal-Wallis $=1.813$; $P=0.404)$. The average number of cells per nest (vestibular cells + provisioned cells) was of 3.3, 4.0 and 3.6 for the nests with $0.7 \mathrm{~cm}, 1.0 \mathrm{~cm}$ and $1.3 \mathrm{~cm}$ in diameter, respectively. Nests with a $1.0 \mathrm{~cm}$ opening diameter had significantly more cells than other nests. The number of provisioned cells was significantly shorter in the $0.7 \mathrm{~cm}$ and $1.3 \mathrm{~cm}$ trap nests than in those with $1.0 \mathrm{~cm}$ in diameter (KruskalWallis = 32.217; $\mathrm{P}<0.001 ; \mathrm{P}_{(0.7 \mathrm{~cm} \times 1.0 \mathrm{~cm})}<0.001$; $\left.\mathrm{P}_{(0.7 \mathrm{~cm} \times 1.3 \mathrm{~cm})}=0.147 ; \mathrm{P}_{(1.0 \mathrm{~cm} \times 1.3 \mathrm{~cm})}=0.047\right)$. The same did not happen with their lengths as $0.7 \mathrm{~cm}$ trap-nests had the largest lengths, followed by $1.0 \mathrm{~cm}$ and finally by $1.3 \mathrm{~cm}$ trap-nests (KruskalWallis = 204.318; $\mathrm{P}<0.001 ; \mathrm{P}_{(0.7 \mathrm{~cm} \times 1.0 \mathrm{~cm})}<0.001$; $\left.\mathrm{P}_{(0.7 \mathrm{~cm} \times 1.3 \mathrm{~cm})}<0.001 ; \mathrm{P}_{(1.0 \mathrm{~cm} \times 1.3 \mathrm{~cm})}=0.002\right)$.

When vestibular cells were analyzed separately, their number ranged from 1 to 2 in all types of trap-nest. Their average length was $1.54 \mathrm{~cm}, 1.14 \mathrm{~cm}$ and $1.26 \mathrm{~cm}$ for the trap-nests with $0.7 \mathrm{~cm}, 1.0 \mathrm{~cm}$ and $1.3 \mathrm{~cm}$, respectively. Their medians were not significantly different (KruskalWallis $=0.2343, \mathrm{P}=0.890)$. Intercalar cells occurred just once in the whole research.

Nest construction usually began with a thin layer of mud in the bottom of the first provisioned cell. Each cell was sealed by a mud partition that

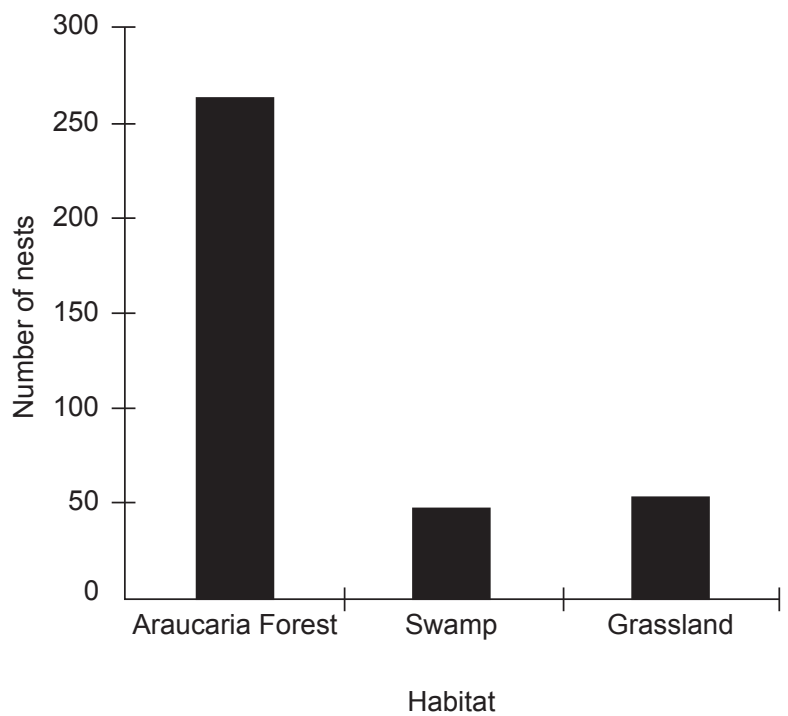

Fig. 1 - Number of nests of T. lactitarse obtained in different habitats from April, 2000 to December, 2003. 


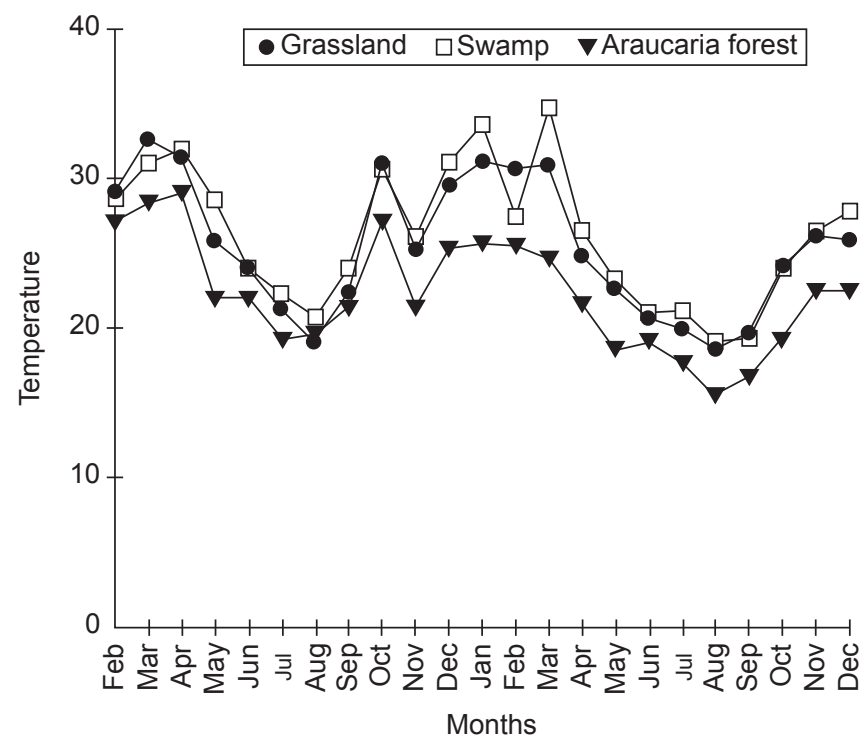

Fig. 2 - Air temperature $\left({ }^{\circ} \mathrm{C}\right)$ in different habitats from February, 2002 to December, 2003.

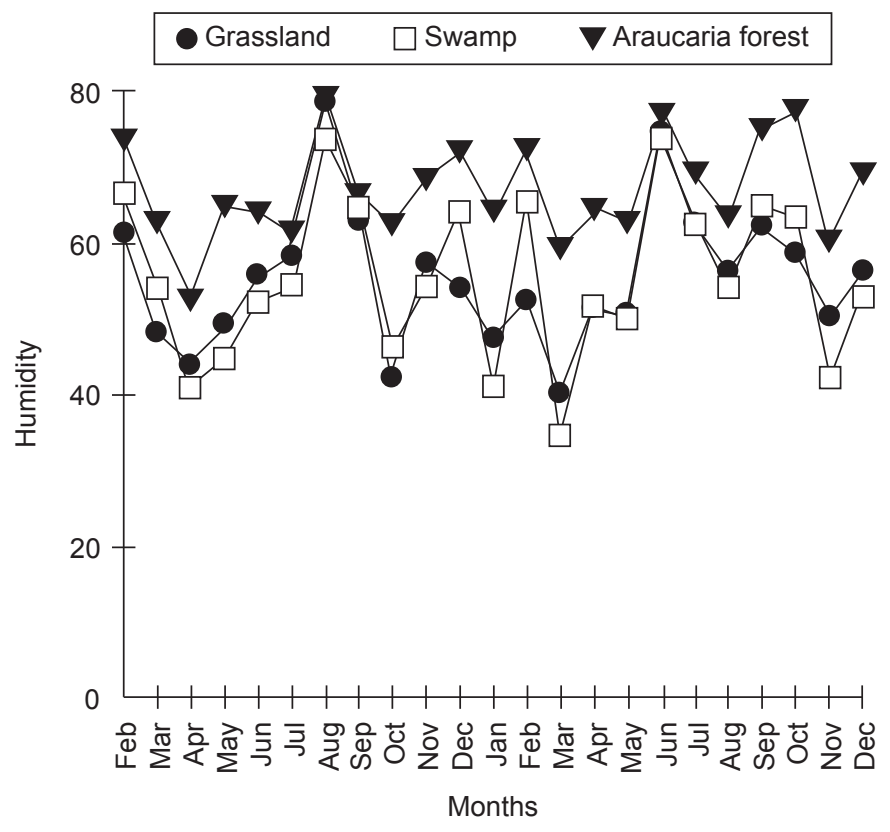

Fig. 3 - Air humidity conditions (\%) in different habitat from February, 2002 to December, 2003.

was rough and convex in the inner side and smooth and concave on the outer side. Finally, there was a closure plug that was often thicker, but otherwise similar to other partitions, except when they had two partitions. The average thickness of closure plugs was $1.54 \mathrm{~cm}, 1.14 \mathrm{~cm}$ and $1.26 \mathrm{~cm}$ for the nests with $0.7 \mathrm{~cm}, 1.0 \mathrm{~cm}$ and $1.3 \mathrm{~cm}$ diameter, respectively.
Cell volume from nests with $0.7 \mathrm{~cm}$ was significantly smaller than those from 1.0 and $1.3 \mathrm{~cm}$ in diameter, both in female (Kruskall Wallis $=127.800 ; \mathrm{P}=0.004)$ and in male cells (Kruskall Wallis $=141.494 ; \mathrm{P}<0.001)$. Male cell volumes were significantly smaller than female cells in $1.0 \mathrm{~cm}$ (Mann-Whitney $\left(\$ 1.0 \mathrm{~cm} \times \delta^{31.0 \mathrm{~cm})}=4,831.50\right.$; 


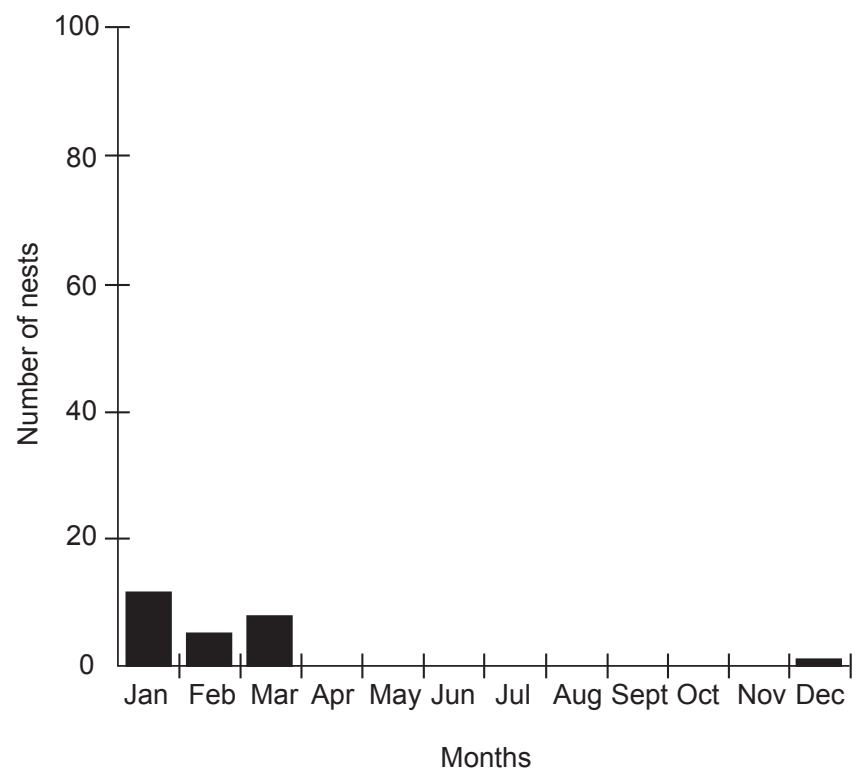

Fig. 4 - Seasonal variation in the number of nests of T. lactitarse obtained monthly from April, 2000 to April, 2002 (first sampling period).

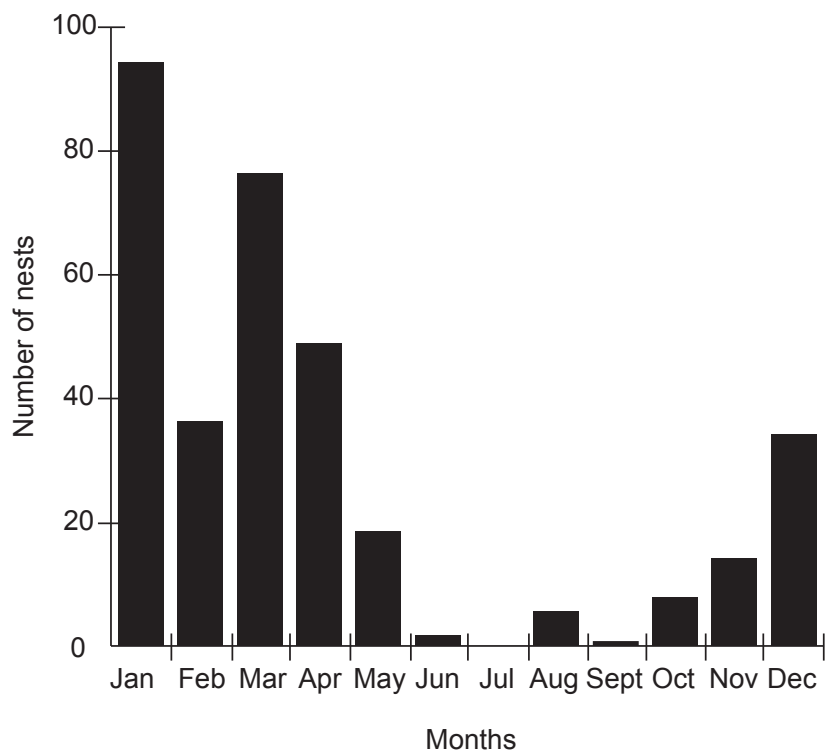

Fig. 5 - Seasonal variation in the number of nests of T. lactitarse obtained monthly from January, 2002 to December, 2003 (second sampling period).

$\mathrm{P}<0.000)$ and $1.3 \mathrm{~cm}($ Mann-Whitney $(\$ 1.3 \mathrm{~cm} \times 1.3 \mathrm{~cm})=$ 248.000; $\mathrm{P}=0.033$ ) trap nests, but were similar in those with $0.7 \mathrm{~cm}$ (Mann-Whitney $(90.7 \mathrm{~cm} \times 80.7 \mathrm{~cm})=$ 154.000; $\mathrm{P}=0.506$ ).

A two-way ANOVA comparing the weights of males and females which came from trap-nests of different diameters showed that females were significantly heavier than the males $(\mathrm{F}=75.372$; $\mathrm{P}<0.001)$. Individuals which came from trapnests of different diameters differed significantly in weight, regardless of their sex $(\mathrm{F}=13.947$; $\mathrm{P}<0.001$ ) (Table 2). However, an a posteriori 


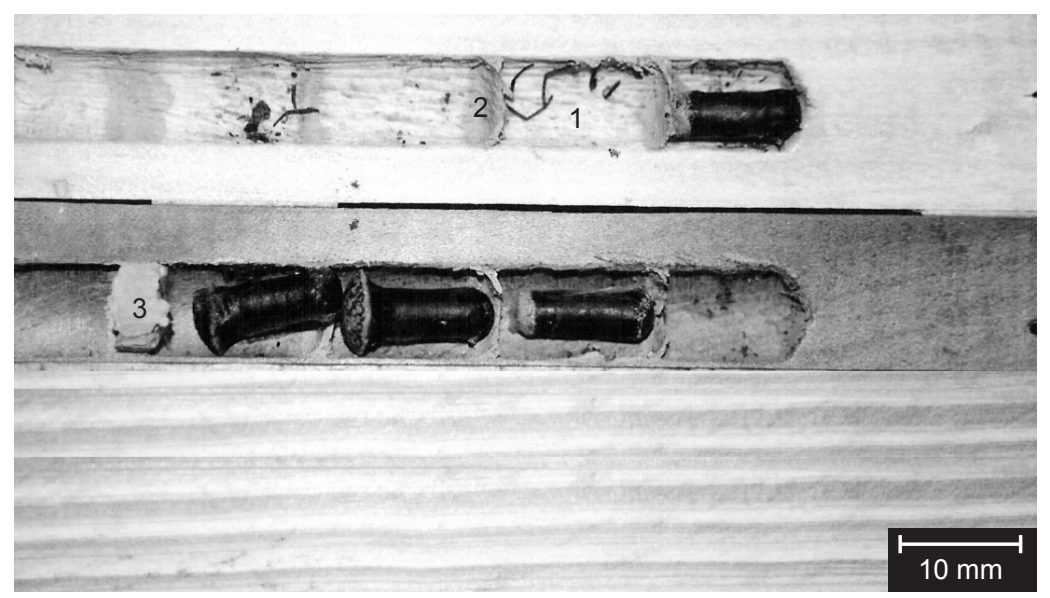

Fig. 6 - Nest of T. lactitarse established in trap-nest with linear cells (1), cells partion (2), nest plug (3), type 1 cocoon, with a coarsely granular, light gray surface and a rounded anterior end, and type 2 cocoon, with an anterior end rough, truncate and strongly expanded.

TABLE 1

Structure of nests of $T$. lactitarse in trap-nests of different diameters.

\begin{tabular}{|c|c|c|c|}
\hline & Trap-nest & Diameter & \\
\hline Nest structure & 0.7 & 1.0 & 1.3 \\
\hline Total nest length & $\begin{array}{c}\bar{X}=7.41 \pm 1.21 \\
n=68 \\
\text { Median }=7.81\end{array}$ & $\begin{array}{c}\bar{X}=7.33 \pm 1.39 \\
n=147 \\
\text { Median }=8.21\end{array}$ & $\begin{array}{c}X=6.81 \pm 1.65 \\
n=45 \\
\text { Median }=6.88\end{array}$ \\
\hline Total number of cells & $\begin{array}{c}\bar{X}=3.3 \pm 1.10 \\
n=110 \\
\text { Median }=4.0\end{array}$ & $\begin{array}{c}\bar{X}=4.0 \pm 1.1 \\
n=172 \\
\text { Median }=4.0\end{array}$ & $\begin{array}{c}X=3.6 \pm 1.1 \\
\quad n=55 \\
\text { Median }=4.0\end{array}$ \\
\hline Number of vestibular cells & $\begin{array}{c}\mathrm{X}=1.1 \pm 0.30 \\
\mathrm{n}=60 \\
\text { Median }=1.0\end{array}$ & $\begin{array}{c}\bar{X}=1.1 \pm 0.3 \\
n=100 \\
\text { Median }=1.0\end{array}$ & $\begin{array}{c}\mathrm{X}=1.1 \pm 0.2 \\
\mathrm{n}=18 \\
\text { Median }=1.0\end{array}$ \\
\hline Number of provisioned cells & $\begin{array}{c}\bar{X}=1.94 \pm 0.46 \\
n=199 \\
\text { Median }=1.89\end{array}$ & $\begin{array}{c}\bar{X}=3.3 \pm 0.9 \\
n=172 \\
\text { Median }=4.0\end{array}$ & $\begin{array}{c}X=3.3 \pm 0.9 \\
\quad n=55 \\
\text { Median }=3.0\end{array}$ \\
\hline Vestibular cell length & $\begin{array}{c}\bar{X}=1.54 \pm 1.07 \\
n=41 \\
\text { Median }=1.43\end{array}$ & $\begin{array}{c}\bar{X}=1.14 \pm 0.83 \\
n=97 \\
\text { Median }=0.93\end{array}$ & $\begin{array}{c}X=1.26 \pm 0.78 \\
n=17 \\
\text { Median }=0.98\end{array}$ \\
\hline Provisioned cell length & $\begin{array}{c}\bar{X}=1.94 \pm 0.46 \\
n=199 \\
\text { Median }=1.89\end{array}$ & $\begin{array}{c}\bar{X}=1.60 \pm 0.19 \\
n=496 \\
\text { Median }=1.59\end{array}$ & $\begin{array}{c}X=1.54 \pm 0.19 \\
n=136 \\
\text { Median }=1.53\end{array}$ \\
\hline Male cell volume $\left(\mathrm{cm}^{3}\right)$ & $\begin{array}{c}\bar{X}=0.693 \pm 0.100 \\
n=75 \\
\text { Median }=0.696\end{array}$ & $\begin{array}{c}\bar{X}=1.210 \pm 0.131 \\
\mathrm{n}=87 \\
\text { Median }=1.213\end{array}$ & $\begin{array}{c}\mathrm{X}=2.146 \pm 0.382 \\
\mathrm{n}=15 \\
\text { Median }=2.128\end{array}$ \\
\hline Female cell volume $\left(\mathrm{cm}^{3}\right)$ & $\begin{array}{c}\bar{X}=0.773 \pm 0.04 \\
n=5 \\
\text { Median }=0.727\end{array}$ & $\begin{array}{c}\bar{X}=1.288 \pm 0.146 \\
n=168 \\
\text { Median }=1.295\end{array}$ & $\begin{array}{c}X=2.326 \pm 0.227 \\
n=52 \\
\text { Median }=2.307\end{array}$ \\
\hline Thickness of cell partition & $\begin{array}{c}\bar{X}=0.19 \pm 0.05 \\
n=164 \\
\text { Median }=0.19\end{array}$ & $\begin{array}{c}\bar{X}=0.21 \pm 0.08 \\
n=445 \\
\text { Median }=0.20\end{array}$ & $\begin{array}{c}\mathrm{X}=0.19 \pm 0.06 \\
\mathrm{n}=124 \\
\text { Median }=0.18\end{array}$ \\
\hline Thickness of closure plug & $\begin{array}{c}\bar{X}=0.24 \pm 0.09 \\
n=87 \\
\text { Median }=0.23\end{array}$ & $\begin{array}{c}\bar{X}=0.27 \pm 0.10 \\
n=162 \\
\text { Median }=0.26\end{array}$ & $\begin{array}{c}X=0.27 \pm 0.12 \\
n=48 \\
\text { Median }=0.26\end{array}$ \\
\hline
\end{tabular}


Tukey test showed that this difference was only due to females, given that the male average weight did not differ among trap-nests, nor with females from trap-nests with $0.7 \mathrm{~cm}$ of diameter. Female $1.3 \mathrm{~cm}$ trap-nests were significantly heavier than those from trap-nests with $1.0 \mathrm{~cm}$ and $0.7 \mathrm{~cm}$ of diameter. The interaction between these two factors (sex and trap-nests diameter) was also significant $(\mathrm{F}=5.547 ; \mathrm{P}=0.004)$.

\section{Cocoon structure}

Two types of cocoon were observed in the present study (Table 2). The first type has a coarsely granular, light gray surface and a rounded anterior end, whereas in the second type the anterior end is rough, truncate and significantly expanded, with a diameter similar to that of the nest tube (Fig. 6). Regardless of the type of cocoon, they were brittle, dark brown, somewhat shiny, smooth and cylindrical, with a round posterior end.

The frequency of both types of cocoons were different between trap nests and $98 \%$ of the cocoons in the $1.3 \mathrm{~cm}$ trap nest were of the first type. This proportion dropped to $68.4 \%$ in $1.0 \mathrm{~cm}$ trap nests and further to $12 \%$ in 0.7 trap-nests. Both females (65.8\%) and males (59.9\%) emerged more frequently from cocoons of the first type.

The cocoon length was significantly shorter in males than in females (Mann-Whitney $(\$ 1.0 \mathrm{~cm}$ type 1 cocoon $\times 31.0 \mathrm{~cm}$, type 1 cocoon) $=3,574.500 ; \mathrm{P}<0.001$, Mann-Whitney $\left.{ }_{\text {cocoon })}=480.500 \mathrm{P}<0.001\right)$ regardless of the type of cocoon (Mann-Whitney ( $\$ 1.0 \mathrm{~cm}$ type 1 cocoon $\times \$ 1.0 \mathrm{~cm}$ type 2 cocoon) $=1,560.500 ; \quad P=0.701)$ or of trap-nest diameter (Mann-Whitney

TABLE 2

Dimensions (cm) of male and female cocoons and adults weights ( $\mathrm{mg}$ ) of T. lactitarse obtained from three types of trap-nests.

\begin{tabular}{|c|c|c|c|}
\hline & Trap-nests & Diameter & \\
\hline & 0.7 & 1.0 & 1.3 \\
\hline Type 1 cocoon length $(q)$ & $*$ & $\begin{array}{c}X=1.60 \pm 0.11 \\
n=68 \\
\text { Median }=1.62\end{array}$ & $\begin{array}{c}X=1.63 \pm 0.05 \\
n=46 \\
\text { Median }=1.63\end{array}$ \\
\hline Type 2 cocoon lenght $(+)$ & $\begin{array}{c}X=1.55 \pm 0.09 \\
n=3 \\
\text { Median }=1.57\end{array}$ & $\begin{array}{c}X=1.62 \pm 0.07 \\
n=44 \\
\text { Median }=1.62\end{array}$ & $\begin{array}{c}X=1.56 \pm 0.01 \\
n=2 \\
\text { Median }=1.56\end{array}$ \\
\hline Type 1 cocoon diameter $(q)$ & $*$ & $\begin{array}{c}X=0.524 \pm 0.04 \\
n=68 \\
\text { Median }=0.525\end{array}$ & $\begin{array}{c}X=0.530 \pm 0.04 \\
n=46 \\
\text { Median }=0.530\end{array}$ \\
\hline Type 2 cocoon diameter $(+)$ & $\begin{array}{c}X=0.622 \pm 0.07 \\
n=3 \\
\text { Median }=0.650\end{array}$ & $\begin{array}{c}X=0.933 \pm 0.04 \\
n=44 \\
\text { Median }=0.933\end{array}$ & $\begin{array}{c}\mathrm{X}=1.11 \pm 0.03 \\
\mathrm{n}=2 \\
\text { Median }=1.11\end{array}$ \\
\hline Type 1 cocoon length $(\grave{o})$ & $\begin{array}{c}\mathrm{X}=1.51 \pm 0.09 \\
\mathrm{n}=4 \\
\text { Median }=1.53\end{array}$ & $\begin{array}{c}\mathrm{X}=1.51 \pm 0.07 \\
\mathrm{n}=67 \\
\text { Median }=1.51\end{array}$ & $\begin{array}{c}\mathrm{X}=1.52 \pm 0.04 \\
\mathrm{n}=11 \\
\text { Median }=1.51\end{array}$ \\
\hline Type 2 cocoon lenght $\left(\delta^{\lambda}\right)$ & $\begin{array}{c}X=1.51 \pm 0.07 \\
n=56 \\
\text { Median }=1.51\end{array}$ & 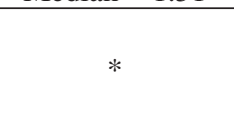 & (19) \\
\hline Type 2 cocoon diameter $\left(\delta^{\Uparrow}\right)$ & $\begin{array}{c}X=0.634 \pm 0.05 \\
n=56 \\
\text { Median }=0.640\end{array}$ & * & $*$ \\
\hline Female weight & $\begin{array}{c}X=54.3 \pm 7.5 \\
n=7 \\
\text { Median }=53.9\end{array}$ & $\begin{array}{c}X=66.2 \pm 9.6 \\
n=175 \\
\text { Median }=67.0\end{array}$ & $\begin{array}{c}X=70.7 \pm 9.2 \\
n=66 \\
\text { Median }=70.1\end{array}$ \\
\hline Male weight & $\begin{array}{c}\mathrm{X}=50.5 \pm 9.0 \\
\mathrm{n}=80 \\
\text { Median }=49.4\end{array}$ & $\begin{array}{c}X=50.7 \pm 7.6 \\
n=105 \\
\text { Median }=50.8\end{array}$ & $\begin{array}{c}\mathrm{X}=54.3 \pm 6.2 \\
\mathrm{n}=29 \\
\text { Median }=55.1\end{array}$ \\
\hline
\end{tabular}

*No cocoon formed. 
cocoon) $=379.500 ; \mathrm{P}=0.870$, Mann-Whitney $(\$ 1.0 \mathrm{~cm}$ type 1 cocoon $x+1.3 \mathrm{~cm}$ type 1 cocoon) $=1,463.500 ; \mathrm{P}=0.561)$.

Type 1 male cocoons were significantly wider in the diameter of their anterior end than type 1 female cocoons both in $1.0 \mathrm{~cm}$ trap-nests (MannWhitney $=869.000 ; \mathrm{P}<0.001)$ and in $1.3 \mathrm{~cm}$ trapnests (Mann-Whitney $=368.000 ; \mathrm{P}=0.020)$. This measure was also significantly wider in type 2 female cocoons than in type 1 female cocoons from $1.0 \mathrm{~cm}$ trap-nests (Mann-Whitney = 2,992.000; $\mathrm{P}<0.001)$. However, there was no difference between type 1 cocoons from different trap-nests both in the case of females (Mann-Whitney ${ }_{(\$ 1.0 \mathrm{~cm} \mathrm{x}}$ $1.3 \mathrm{~cm}$ ) $=1,701.500 ; \mathrm{P}=0.426$ ) and in males (MannWhitney $\left({ }_{(1.0 \mathrm{~cm} \times 1.3 \mathrm{~cm})}=264.500 ; \mathrm{P}=0.134\right)$.

\section{Life-history and sex ratios}

T. lactitarse had two types of life cycles: direct development (without diapause), and delayed development (with diapause during winter) (Table 3). Males from $0.7 \mathrm{~cm}$ trap nests developed in a shorter time than males from 1.0 and $1.3 \mathrm{~cm}$ trap nests in the case of delayed development (Kruskal-Wallis $=13.425 ; \mathrm{P}=0.003)$. Males from 1.0 and $1.3 \mathrm{~cm}$ trap nests had similar developmental times (Kruskal-Wallis = 13.425; $\mathrm{P}=0.305)$. Developmental time was similar between females of different trap nests (MannWhitney $=1,858.500 ; \quad \mathrm{P}=0.090$ ), as well as between males and females from the same trap nest size (Mann-Whitney $(\$ 1.0 \mathrm{~cm} \times \$ 1.0 \mathrm{~cm}): 2,204.00$; $\mathrm{P}=0.830$, Mann-Whitney $\left(\begin{array}{c}1.3 \mathrm{~cm} \times 81.3 \mathrm{~cm} \\ \mathrm{P}\end{array}\right): 292.00$; $\mathrm{P}=0.905)$

In the case of direct development, although the males developed in a shorter time than the females, the only significant difference occurred between females and males from $1.3 \mathrm{~cm}$ trap-nests

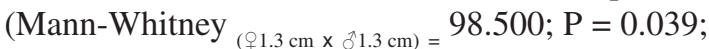
Mann-Whitney $(\mathrm{P} 1.0 \mathrm{~cm} \times 11.0 \mathrm{~cm})=843.500 ; \mathrm{P}=0.140$; Mann-Whitney $(90.7 \mathrm{~cm} \times 80.7 \mathrm{~cm})=81.000 ; \mathrm{P}=0.887)$. No difference in development time was detected between wasps of the same sex from different type of trap-nests (Kruskal-Wallis $=0.004 ; \mathrm{P}=0.998$; Kruskal-Wallis $\left._{\text {} \odot}=0.320 ; \mathrm{P}=0.852\right)$.

\section{Mortality and natural enemies}

A total of 310 provisioned cells were found in $0.7 \mathrm{~cm}$ trap-nest, of which $191(61.6 \%)$ resulted in the death of enclosed individuals. The most important mortality factor was the death of immature forms, which were observed in 144 cells (46.5\%), possibly due to development failure in the egg (1.3), larva $(34.2 \%)$ or pupa $(6.8 \%)$ stage. No egg or larva was found in 13 cells (4.2\%). Parasitoids occurred

TABLE 3

Development time in both cycle types (days) of females and males in $0.7,1.0$ and $1.3 \mathrm{~cm}$ trap-nests.

\begin{tabular}{|c|c|c|c|}
\hline & & $\begin{array}{c}\text { Direct development } \\
\text { (without diapause) }\end{array}$ & $\begin{array}{l}\text { Delayed development } \\
\text { (with diapause) }\end{array}$ \\
\hline \multirow[t]{2}{*}{0.7} & Females & $\begin{array}{c}\bar{X}=50.00 \pm 3.92 \\
n=7 \\
\text { Median }=49.00\end{array}$ & $*$ \\
\hline & Males & $\begin{array}{c}\bar{X}=50.00 \pm 3.84 \\
n=24 \\
\text { Median }=50.00\end{array}$ & $\begin{array}{c}\bar{X}=260.07 \pm 37.17 \\
n=60 \\
\text { Median }=265.00\end{array}$ \\
\hline \multirow[t]{2}{*}{1.0} & Females & $\begin{array}{c}\bar{X}=50.49 \pm 6.77 \\
n=49 \\
\text { Median }=51.00\end{array}$ & $\begin{array}{c}\bar{X}=270.67 \pm 41.17 \\
n=98 \\
\text { Median }=278.50\end{array}$ \\
\hline & Males & $\begin{array}{c}\bar{X}=48.83 \pm 6.20 \\
n=42 \\
\text { Median }=48.00\end{array}$ & $\begin{array}{c}\bar{X}=275.98 \pm 26.64 \\
n=46 \\
\text { Median }=277.00\end{array}$ \\
\hline \multirow[t]{2}{*}{1.3} & Females & $\begin{array}{c}X=50.82 \pm 3.57 \\
n=22 \\
\text { Median }=50.00\end{array}$ & $\begin{array}{c}\bar{X}=283.63 \pm 35.96 \\
n=46 \\
\text { Median }=286.50\end{array}$ \\
\hline & Males & $\begin{array}{c}\bar{X}=47.27 \pm 5.78 \\
n=15 \\
\text { Median }=49.00\end{array}$ & $\begin{array}{c}\bar{X}=286.31 \pm 26.52 \\
n=13 \\
\text { Median }=287.00\end{array}$ \\
\hline
\end{tabular}

*No female available. 
in 42 cells $(13.6 \%)$. Chrysididae (Hymenoptera) accounted for $5.5 \%$ of the cases, followed by Sarcophagidae (Diptera) (4.5\%), Dolichopodidae (Diptera) (1.6\%), Ichneumonidae (Hymenoptera) $(0.7 \%)$. Four death cases occurred by unidentified parasitoids $(1.3 \%)$. In five cases (1.6\%), the adults died inside the nest as they emerged but apparently could not go through the mud partitions.

In $1.0 \mathrm{~cm}$ trap-nests, 537 provisioned cells were found, of which $218(40.6 \%)$ resulted in the death of enclosed individuals. Dead immatures were observed in 155 cells ( $28.9 \%)$, probably due to development failure that occurred in the egg $(1.3 \%)$, larva (19.6\%) or pupa (4.4\%) stage. No egg or larva was found in 19 cells (3.5\%). Fifty two cells $(9.7 \%)$ were attacked by parasitoids. Chrysididae (Hymenoptera) accounted for $5.4 \%$ of the cases, followed by Ichneumonidae (Hymenoptera) (2.4\%), Dolichopodidae (Diptera) (1.7\%) and Sarcophagidae (Diptera) $(0.2 \%)$. In 11 cases $(2.1 \%)$ the adults died inside the nest as they emerged but apparently could not go through the mud partitions.

In $1.3 \mathrm{~cm}$ trap nests, 186 provisioned cells were found, of which $82(44.1 \%)$ resulted in the death of enclosed individuals. Dead immatures were observed in 42 cells $(22.6 \%)$, probably due to development failure that occurred in the larva $(14.5 \%)$ or pupa (3.8\%) stage. No egg or larva was found in 8 cells (4.3\%). Thirty five cells (18.8\%) were attacked by parasitoids. Sarcophagidae (Diptera) accounted for $6.5 \%$ of the cases, followed by Dolichopodidae (Diptera) (4.8\%), Chrysididae (Hymenoptera) (4.3\%) and Ichneumonidae (Hymenoptera) (2.7\%). In 5 cases $(2.7 \%)$ the adults died inside the nest as they emerged, but apparently could not go through the mud partitions.

\section{Collected prey}

Out of 1,353 identified spider prey, 1,313 $(97.0 \%)$ belonged to the family Araneidae. The most common prey species in this family were Eustala $\mathrm{sp}_{1}(\mathrm{n}=181)$, followed by Eustala $\mathrm{sp}_{2}(\mathrm{n}=137)$, Acacesia villalobosi $(\mathrm{n}=72)$, Larinia t-notata $(\mathrm{n}=39)$, Araneus corporosus $(\mathrm{n}=34)$, Eustala $\mathrm{sp}_{3}(\mathrm{n}=28)$, Eustala $\mathrm{sp}_{4}(\mathrm{n}=20)$, Mangora $\mathrm{sp}_{1}$ $(\mathrm{n}=19)$, Wagneriana iguape $(\mathrm{n}=10)$, Alpaida $\mathrm{sp}_{1}(\mathrm{n}=8)$, Araneus blumenau $(\mathrm{n}=8)$, Eustala $\mathrm{sp}_{5}$ $(\mathrm{n}=5)$, Wagneriana eupalaestris $(\mathrm{n}=5)$, Ocrepeira galianoe $(\mathrm{n}=5)$, Eustala $\mathrm{sp}_{6}(\mathrm{n}=4)$, Alpaida grayi $(\mathrm{n}=4)$, Alpaida $\mathrm{sp}_{2}(\mathrm{n}=4)$, Araneus aff omnicolor $(\mathrm{n}=3)$, Mangora $\mathrm{sp}_{2}(\mathrm{n}=3)$, Alpaida scriba $(\mathrm{n}=2)$, Bertrana rufostriata $(\mathrm{n}=2)$, Araneus omicolor $(\mathrm{n}=1)$, Eustala $\mathrm{sp}_{7}(\mathrm{n}=1)$, Mangora $\mathrm{sp}_{5}(\mathrm{n}=1)$, Alpaida veniliae $(\mathrm{n}=1)$, Wagneriana negleta $(\mathrm{n}=1)$, Wagneriana $\mathrm{sp}_{1}(\mathrm{n}=1)$, Wagneriana janeiro $(\mathrm{n}=1)$, Araneus aurantiifemuris $(\mathrm{n}=1)$, Metazigia gregalis $(\mathrm{n}=1)$, as well as 711 unidentified araneid juveniles.

The second more common family of spiders used as prey was Anyphaenidae ( $\mathrm{n}=31$ spiders). Twenty three of them were in a juvenile stage and were not identified. Aysha gr brevimana 1 was the most common species $(\mathrm{n}=6)$, followed by Aysha $\mathrm{sp}_{3}(\mathrm{n}=1)$ and Aysha aff borgmeyeri $(\mathrm{n}=1)$.

Other spider families collected by $T$. lactitarse included Tetragnathidae (Leucage $\mathrm{sp}(\mathrm{n}=1$ juvenile), Chrysometa boraceia $(\mathrm{n}=1)$ and an unidentified juvenile), Oxyopidae ( $\mathrm{n}=1$ unidentified juvenile), Deinopidae (Deinops sp. ( $\mathrm{n}=1$ juvenile), Salticidae $(\mathrm{n}=1$ unidentified juvenile) and Uloboridae (Miagrammopes $\mathrm{sp}_{1}, \mathrm{n}=1$ juvenile).

\section{DISCUSSION}

As also observed by Camillo et al. (1993) and by Assis \& Camillo (1997), nesting activity of T. lactitarse in Guarapuava, was most common during the warm season and was interrupted by diapause in the winter.

Although T. lactitarse did not occur exclusively in the Araucaria Forest, its preference for this habitat was clear. This result differs from what was found by Perez-Maluf (1993) where nesting was most frequent outside the forest than inside it. According to her, this result is associated with factors such as the abundance of natural nesting holes.

Temperature, humidity and insolation may play an important role in determining the preference of a species for a given habitat. During the present study, Araucaria Forest had lower insolation, with lower air temperature and higher air humidity than the grassland and swamp areas.

A preference of $T$. lactitarse for $1.0 \mathrm{~cm}$ trap nest openings was also found by Camillo et al. (1993), Perez-Maluf (1993) and Assis \& Camillo (1997). In addition to the variation between species of Trypoxylon in the number of provisioned cells, more than one type of trap-nest can be used by the same species (Assis \& Camillo, 1997). PerezMaluf (1993) observed variations in the choice of 
trap-nest diameter in T. lactitarse. We obtained the same results, that is, a substantial range of the number of provisioned cells according to the trapnest diameter.

No difference in the number of vestibular cells was observed between trap nests in the present study, contrary to what was found by Coville (1981). Moreover, although a single intercalar cell was recorded in our study, it was commonly observed in T. lactitarse nests in Southeast Brazil by Camillo et al. (1993) and Assis \& Camillo (1997).

As observed by Camillo et al. (1993), females of $T$. lactitarse started their nests by building a mud layer in the bottom of the first cell. All the cell partitions were rough and convex on the inner side and smooth and concave on the outer side. The closure plug had the same characteristics and was constructed at the entrance of the tube or recessed from it and often consisted of two mud layers.

The observed difference between female and male cell volume and between individuals from the same sex, but from different types of trap-nests is not compatible with what was observed by Camillo et al. (1993) for T. lactitarse and by Assis \& Camillo (1997) for other wasp species. They found that, regardless of the type of trap-nest, the lengths of male and female cells were similar.

The cocoon types of T. lactitarse and their structure were similar to those described by PerezMaluf (1993) and by Assis \& Camillo (1997). In addition to the two types of cocoon found in our study, Camillo et al. (1993) and Camillo et al. (1994) found one third type with an intermediate shape between these two types.

Apparently, there is not a sex positioning pattern within nests of Trypoxylon species. We observed that in T. lactitarse, the female and male positioning was indeed random. The same result was found by Coville (1981) for T. nitidium schulthessi. However, Camillo et al. (1993) observed that the males and females of $T$. lactitarse tended to emerge from inner and outer cells, respectively. The opposite sex distribution was found by Assis \& Camillo (1997) in other Trypoxylon species, with males emerging from outer cells and females from inner cells.

Although the information in Figs. 5 and 6 is not sufficient to test whether T. lactitarse is bivoltine, the investigation of its life-history showed that it actually has two generations per year. Camillo et al. (1994) observed that T. rogenhoferi had four generations per year in tropical and subtropical regions. Our results, combined with the evidence above, supports the suggestion by Coville (1982) that wasps in temperate regions are usually univoltines or have a second partial generation, whereas in tropical and subtropical regions they are bivoltines or multivoltines. The explanation for the presence of more than a generation per year needs to consider environmental factors such as climatic conditions. Air temperature is one of the most important factors modulating insect diapause (Silveira Neto et al., 1976). Because Guarapuava is located in a subtropical region and is considered one of the coldest cities in the state of Parana, low air temperature during fall and winter could in fact be the main factor generating diapause in these wasps.

As also observed by Seger (1983) in a few species of Sphecidae, and by Brockmann and Grafen (1992) in T. politum, we found that T. lactitarse had two types of development. Moreover, Brockmann \& Grafen (1992) observed juvenile development time similar to our data.

The numerical sex ratio in our study was not significantly different from $1: 1$, contrary to what was observed by Assis \& Camillo (1997), where the sex ratio in $T$. lactitarse was male-biased in all studied conditions. Variable sex allocation may evolve in response to a number of factors in species with overlapping generations such as the variation between the generation in diapause, population recruitment or mortality rates (Seger, 1983; West \& Godfray, 1997).

Mortality factors observed in our study were similar to those reported by other authors for T. lactitarse. Perez-Maluf (1993) observed a mortality rate of $51.5 \%$ in 225 cells. According to her, $58.7 \%$ of those deaths were probably caused by development failure and $41.3 \%$ resulted from attacks by parasitoids such as Chrysididae, Sarcophagidae, Ichneumonidae, Megaselia (Phoridae) and Melittobia sp. (Eulophidae). Camillo et al. (1993) observed that $31.8 \%$ of all T. lactitarse nest cells did not complete development to the adult stage, with $24.1 \%$ of them being parasitized and $7.7 \%$ containing dead juveniles.

According to Genaro et al. (1989), one of the most important factors in the study of sphecid nesting behavior is the record of captured prey species. Wasps of the same species may vary in their prey preferences because they hunt in 
different areas (Coville, 1987). In Guarapuava, $T$. lactitarse showed a strong preference for species of the Araneidae family and Eustala was the most frequently collected item (52.9\%). Similar results were obtained by other authors (Coville, 1981; Camillo et al., 1993; Camillo \& Brescovit, 1999ab). Camillo \& Brescovit (1999b) reported that, although T. lactitarse also preyed heavily on Eustala spp. in Southeastern Brazil, such a strong preference for spiders of this genus is uncommon among species of Trypoxylon (Trypargilum) and is restricted to $T$. lactitarse and T. politum (Cross et al., 1975) as well as T. monteverdae (Brockmann, 1992).

Acknowledgments - Partial financial support was provided by Fundação Araucária (The State of Paraná Research Foundation) and UNICENTRO (Guarapuava - PR, Brazil).We thank Prof. Dr. Miguel Petrere Jr. from UNESP (Rio Claro-SP, Brazil) for the statistical discussion. We also thank Prof. Dr. Antônio D. Brescovit from the Instituto Butantan (SP, Brazil) for identifying the spiders, Prof. Dr Sérvio Túlio Amarante from the Museu de Zoologia da USP (SP, Brazil) for identifying the wasps and Prof. Ms Sérgio Bazílio from UNICENTRO (PR, Brazil) for some help.

\section{REFERENCES}

AGUIAR, A. J. C., 2002, Abelhas e vespas solitárias em ninhosarmadilha na Reserva Biológica Guaribas (Mamanguape, Paraíba, Brasil). Revta Bras. Zool., 19(Supl. 1): 101-116.

ASSIS, J. M. F. \& CAMILLO, E., 1997, Diversidade, sazonalidade e aspectos biológicos de vespas solitárias (Hymenoptera: Sphecidae: Vespidae) em ninhos armadilhas na Região de Ituiutaba, MG. An. Soc. Entomol. Brasil, 26(2): 335-347.

BEYER, W. N., MILLER, G. W. \& FLEMING, W. J., 1987, Populations of trap-nests wasps near a major source of fluoride emissions in Western Tennessee. Proc. Tomol. Soc. Wash., 89(3): 478-482.

BROCKMANN, H. J. \& GRAFEN, A., 1989, Mate conflit and male behaviour in a solitary wasp, Trypoxylon (Trypargilum) politum (Hymenoptera: Sphecidae). Anim. Behav., 37: 232-255.

BROCKMANN, H. J. \& GRAFEN, A., 1992, Sex ratios and life-history patterns of a solitary wasp, Trypoxylon (Trypargilum) politum (Hymenoptera: Sphecidae). Behav. Ecol. Sociobiol., 30: 7-27.

CAMILlO, E., GAROFAlO, C. A., MUCCILlO, G. \& SERRANO, J. C., 1993, Biological observations on Trypoxylon (Trypargilum) lactitarse Saussure in southeastern Brazil (Hymenoptera: Sphecidae). Rev. Bras. Entomol., 37(4): 769-778.

CAMILLO, E., GAROFALO, C. A. \& SERRANO, J. C., 1994, Observações sobre a biologia de Trypoxylon (Trypargilum) rogenhoferi Kohl (Hymenoptera: Sphecidae). An. Soc. Entomol. Brasil, 23(2): 299-309.

CAMillo, E., GAROFAlO, C. A., SERRANO, J. C. \& MUCCILLO, G., 1995, Diversidade e abundância sazonal de abelhas e vespas solitárias em ninhos armadilhas (Hymenoptera, Apocrita, Aculeata). Rev. Bras. Biol, 39(2): 459-470.

CAMILLO, E. \& BRESCOVIT, A. D., 1999a, Aspectos biológicos de Trypoxylon (Trypargilum) lactitarse Saussure e Trypoxylon (Trypargilum) rogenhoferi Kohl (Hymenoptera: Sphecidae) em ninhos-armadilhas, com especial referência a suas presas. An. Soc. Entomol. Brasil, 28(2): 251-261.

CAMILLO, E. \& BRESCOVIT, A. D., 1999b, Spiders (Ananeae) captured by Trypoxylon (Trypargilum) lactitarse (Hymenoptera: Sphecidae) in southeastern Brazil. Rev. Biol. Trop., 47(1-2): 151-162.

CAMILlO, E. \& BRESCOVIT, A. D., 2000, Spider prey (Araneae) of Trypoxylon (Trypargilum) rogenhoferi (Hymenoptera: Sphecidae) in southeastern Brazil. Rev. Biol. Trop., 48(2-3): 647-656.

COVILLE, R. E., 1981, Biological observations on three Trypoxylon wasps in the subgenus Trypargilum from Costa Rica: T. nitidum schulthessi, T. sausurei and T. lactitarse (Hymenoptera: Sphecidae). The Pan-Pacific Entomol., 57(2): 332-40.

COVILLE, R. E., 1982, Wasps of the genus Trypoxylon subgenus Trypargilum in the North America. University of California Press, Berkeley.

COVILLE, R. E., 1987, Spider-hunting sphecid wasps. pp. 309318. In: Ecophysiolosy of spiders. Edited by W. Nintwing. Springer, Berlin.

CROSS, E. A., STITH, M. G. \& BAUMAN, T. R., 1975, Bionomics of the organ-pipe mud-dauber, Trypoxylon politum (Hymenoptera: Sphecidae). Ann. Entomol. Soc. Am., 68: 901-916.

GENARO, J. A., SANCHEZ, C. S. \& ALAYÓN, G., 1989, Notas sobre la conducta de nidificación de Trypoxylon (Trypargilum) subimpressum Smith (Hymenoptera: Sphecidae). Caribbean J. Sci., 25: 228-229.

MORATO, E. F. \& CAMPOS, L. A. O., 2000, Efeitos da fragmentação florestal sobre vespas e abelhas solitárias em uma área da Amazônia Central. Rev. Bras. Zool, 17(2): 429-444.

PÉREZ-MALUF, R., 1993, Biologia de vespas e abelhas solitárias, em ninhos-armadilhas, em Viçosa- MG. M.S. thesis, Universidade Federal de Viçosa, Viçosa, Minas Gerais, Brasil.

PERUQUETTI, R. C. \& DEL LAMA, M. A., 2003. Alocação sexual e seleção sexo-dependente para tamanho de corpo em Trypoxylon rogenhoferi Kohl (Hymenoptera, Sphecidae). Rev. Bras. Entomol, 47(4): 581-588.

SILVEIRA NETO, S., NAKANO, O., BARBIN, D. \& VILLA NOVA, N. A., 1976, Manual de Ecologia dos Insetos. Editora Agronômica Ceres, São Paulo.

SEGER, J., 1983, Partial bivoltinism may cause alternatig sexratio biases that favour eusociality. Nature, 301: 59-92.

WEST, S. A. \& GODFRAY, H. C. J., 1997, Sex ratio strategies after perturbation of the stable age distribution. J. Theor. Biol., 186: 213-221. 
